\title{
The Hybrid Lean System to Improve Manufacturing Environment
}

\author{
Ahmad Nur Aizat Ahmad. ${ }^{1}$, Te Chuan Lee. ${ }^{1}$ Rohaizan Ramlan. ${ }^{1}$, Md. Fauzi Ahmad. ${ }^{1}$, \\ Norafifah Husin ${ }^{2}$ and Mustaqqim Abdul Rahim. ${ }^{3}$ \\ ${ }^{1}$ Department of Production and Operation Management, Faculty of Technology Management and \\ Business, Universiti Tun Hussein Onn Malaysia (UTHM), Malaysia \\ ${ }^{2}$ Department of Industrial Engineering, Faculty of Mechanical Engineering, Universiti Teknologi \\ Malaysia (UTM), Malaysia \\ ${ }^{3}$ Department of Civil Engineering, School of Environmental Engineering, Universiti Malaysia Perlis \\ (UniMAP), Malaysia
}

\begin{abstract}
Lean manufacturing is a systematic approch could increase manufacturing competitiveness by identifying and elminating waste through lean tools. However, these tools are often categorized into different groups, continues to be difficult for companies to select the most appropriate lean tool to be adopted, especially in respect of the SMEs whose knowledge of lean tools and associated principles are limited. This study is to propose solution on how to implement appropriate lean tools in food manufacturing industry located at Rengit, Johor. Qualitative method is used as a methodology to see the changes after the implementation of lean tools. Interview session also a part of method to collect data from respondents. The finding from this paper shows that implementation of an appropriate lean tool will help to eliminate waste in industry sector, maintain and control the inventory, improve quality of the product and improve overall operational process.
\end{abstract}

\section{Introduction}

Lean manufacturing is one of the initiatives that many major manufacturing plants in Asia, especially in Malaysia have been trying to adopt in order to remain competitive in an increasingly competitive global market (Rahani AR, Muhammad al-Ashraf, 2012). The focus of the approach is on reduction of the cost and time through eliminating non value added activities by applying a management philosophy which focused on eliminating and identifying waste from each step in the production chain respective of energy, time, motion and resources alike throughout a product value stream, known as lean.. The term "lean" was first introduced as the "lean production system" by John Krafcik, after a review of the TPS. This was later on popularized as "lean manufacturing" by (Womack et al., 1990) in the book

${ }^{1}$ Corresponding author: aizat@uthm.edu.my 
The Machine that Changed the World. Lean was initially most widely used in manufacturing companies. In recent years, lean manufacturing have been developed and used in varied sectors such as public organizations, military and healthcare. (Liker, 2006). (Bhuiyan et al., 2006) stated that lean production was one of the oldest improvement methodologies, providing high value to the customer by using of best practices such as Kanban, mistake proofing and 5S. Many authors have demonstrated on how and when used appropriately, lean philosophy can help to eliminate the waste in process industry, maintain better inventory control, increase and improve product quality and reduced operational costs and materials.(Gupta and Jain, 2013).

The achievement of a specific management strategy typically relies on organizational characteristics, which infers that all organizational should not or can't execute a comparative arrangement of strategy in their specific case (Shah and Ward, 2003).Wrong use of lean techniques brings about wasteful aspects of an association's assets and diminished employee trust in lean systems (Marvel and Standrigde, 2009). Therefore, applying the proper strategy at the suitable time for the right reasons is very important. The goals proposed in this work will be accomplish by identify lean factors and propose best solution to the company on how to implement appropriate lean tool.

Besides, do a continuous improvement which is combining of two lean elements its called hybrid of lean tools. The wide decision of lean tools accessible to minimize waste can be confused for those with restricted information of limited knowledge of lean tools and their proficiency, thus the introduction of lean tools as often as possible result in a negative effect on organization's effectiveness.

Moreover, Anand and Kodali (2009) indicated that there is a consolidated list of around 60 lean manufacturing tools, while Eswaramoorthi et al. (2011) highlighted that there are 36 different lean tools for machine tool industry. From the above, it can be noticed that there are various lean tools and a few researchers have classes them into various groups. Thus, a methodology to determine suitable lean tools will significantly help organizations in embracing the most appropriate lean tools for their specific aims and objective.

Besides that, there is a limited study about implement of hybrid lean tools. Hybrid of lean management system is a technique or tool of consolidation between two or more elements from lean management system. As significance role of continuous improvement today's organization and lack of adequate proof to demonstrate the positive effect of hybrid lean management system.

Thus, the aims propose in this project is achieved by propose solution and implementation of hybrid lean tools with respect to support manufacturing industry. In order to achieve the lean concept, a case study in manufacturing company to accomplish the objectives for this study: (1) To observe whether the organization applied lean management tool in their organization, (2) To combine the lean tools to become lean hybrid tools, and (3) To identify the benefits of lean hybrid system implementation with respect to the company's performance.

This study is important to give a better understanding for the manufacturing industry that faced of confusing to implement appropriate tools of lean management system. In addition, this research also contributed to the parties to use it as a source of references and guidance such as:

a) Academicians

Academicians could use this research as a source of reference for their further studies either related to this topic or other new upcoming topics. The information and knowledge provided are expected to be beneficial for them in order to improve their lean knowledge. 
b) Manufacturing Industry

This research is expected to propose comprehensive understanding on the challenge faced by the manufacturing company in getting to find an appropriate tool of lean management system to be implemented in the company. Suitable of lean tools can provide enhancement of company's performance and increase effectiveness of the workplace.

This study is focused at manufacturing industry located at Rengit, Johor in the food sector. The project approached an observation around the production line based on case study. The results shown the changes on the company's performance towards the implementation of lean hybrid tools. This study also examines the improvement of the changes towards a better workplace and environment.

\section{Literature Review}

Lean Manufacturing is a concept created to eliminate waste in manufacturing operations. There are various definitions of lean from different view of authors. Todd (2000), mentioned lean as initiative to reduce wastes in inventory, time, human effort and manufacturing space to become highly responsive to customer demand. As enhancement on mass production due to get the product right at time, continuous improvement effort, quality in product and process, flexible production and minimizing waste (Motwani 2003).

Pavnaskar et al (2003) defined lean as a practice to reduce the waste in human effort, inventory, time to market and manufacturing space to become highly responsive to customer demand. Taj \& Berro (2006) defined lean as an approach to reduce waste (Muda) in value stream systematically. As the systematic removal of waste by all members of the organization from all areas of the value stream. (Worley 2004)

\subsection{Waste}

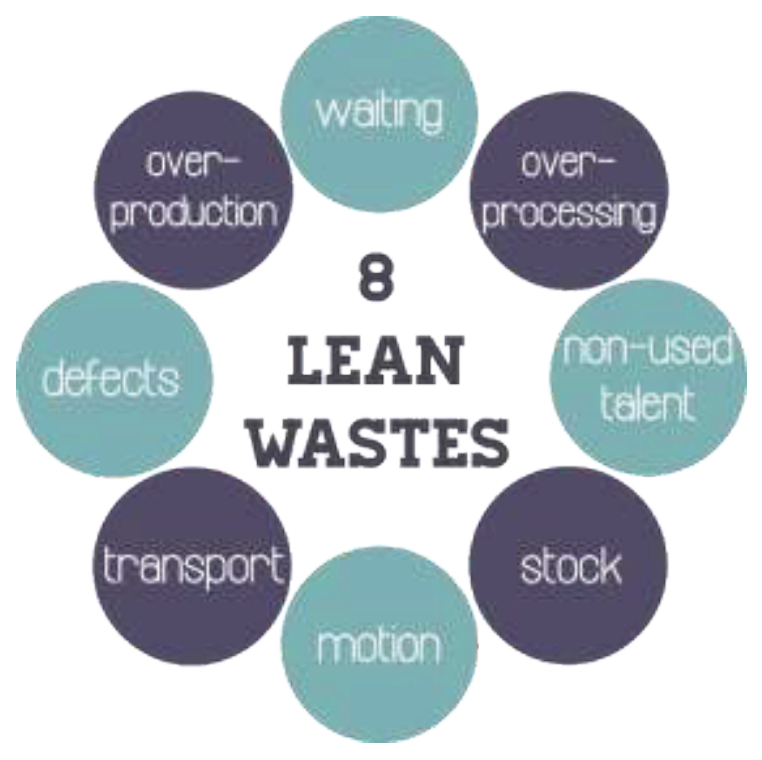

Figure 2.1: Waste of Lean 
There are 8 wastes in manufacturing as stated by Taichi Ohno, the father of Toyota

Production System. Figure 2.1 shown 8 wastes in lean.

\subsection{Continuous Improvement}

The Hybrid of lean management system is a combination of some elements from lean tools to be integrated into two or three elements. This system will help to organize a better workplace for efficiency and reduce waste. Some of the elements are working together to achieve the lean concept. The hybrid lean is the combining of lean elements as examples:

- Kanban, tagging and labeling

- $5 \mathrm{~S}$ and visual control,

- poka yoke and shadow board.

There are similar major studies shown a benefit of implement of lean tools as done by Bevilacqua, Ciarapica, De Sanctis, Mazzuto, \& Paciarotti, 2015) on their research A Changeover Time Reduction through an integration of lean practices: a case study from pharmaceutical sector highlighted that by using an integration of different lean practice can reduce the batch change and changeover time up to 50 per cent, increasing overall equipment effectiveness by 25 per cent.

\section{Methodology}

\subsection{Primary Data}

Primary data is the main data used to obtain information about the study. Primary data collected in this study observe the workplace environment by using pictures to get the real situation of the workplace. Besides, this research also involved interview session with 3 respondents to take their point of view about lean tools. Some data is analyzed using table and other methods for displaying the results in a format that is easy to understand.

\subsection{Research Process Flow}

Research methodology is the systematic way to solve the research problems. There are several steps that are generally adopted by a researcher to conduct a research. This study discussed on a few process part to implement lean tools including measurement, improvement, analysis and implementation as follow:

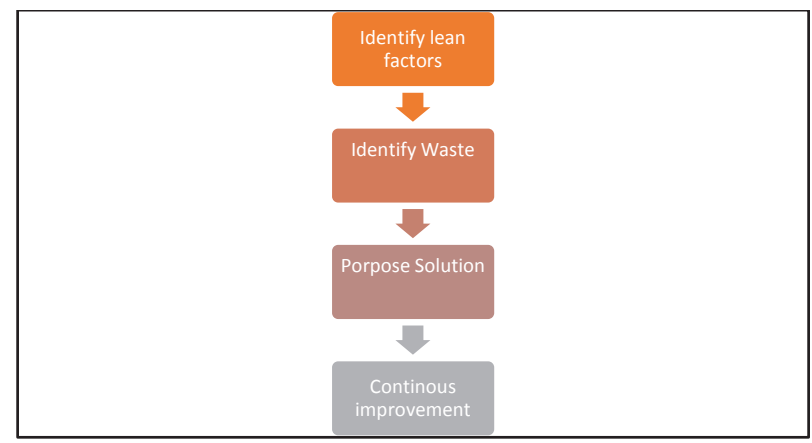

Figure 3.1: Process Flow Chart 
From the process flow chart at studied company, there are 7 types of waste that are used to improve the process flow of the studied company. The waste are:

1) Defects

2) Waiting

3) Inventory

4) Overproduction

5) Transportation

6) Inappropriate processing

7) Unnecessary motion

\subsubsection{Continuous Improvement}

The transition of a lean environment cannot be done in a night. A continuous improvements are necessary to achieve company's goal. The hybrid lean management systems which are the combining of two or more lean method/tools are used to make the continuous improvement. This system helped and organized a better workplace for efficiency and reduced waste. Some of the elements are working together to achieve the lean concept. The hybrid that combining the lean elements as examples are: labeling, tagging, 5S, visual control, and poka yoke. The hybrid lean is the combination of leans element such as $5 \mathrm{~S}$ system and tagging, visual control and $5 \mathrm{~S}$ and etc. The details explanation of these elements as in table below:

Table 3.1 Definition of each element

\begin{tabular}{|c|c|}
\hline Element & Definition \\
\hline $5 \mathrm{~S}$ & 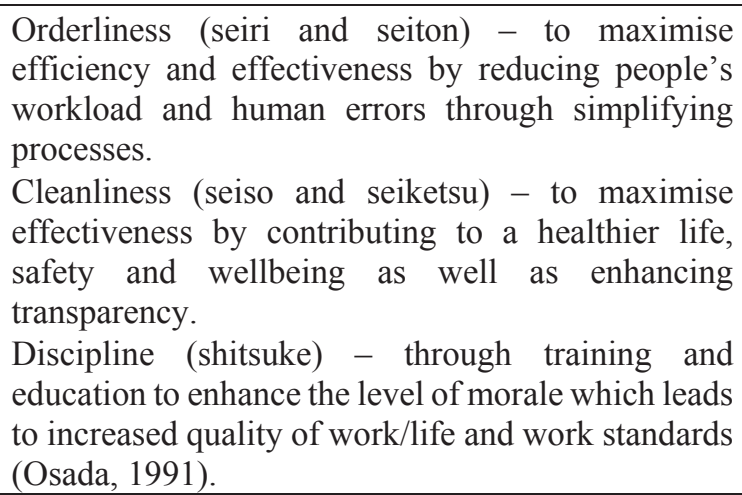 \\
\hline Visual control & $\begin{array}{l}\text { Visual control is a business management technique } \\
\text { employed in many places where information is } \\
\text { communicated by using visual signals instead of } \\
\text { texts or other written instructions. The design is } \\
\text { deliberate in allowing quick recognition of the } \\
\text { information being communicated. Santos et al. } \\
\text { (2001) found that visual controls provided and } \\
\text { enabled increased efficiency, and that conversely, a } \\
\text { lack of visual controls inhibited increased } \\
\text { efficiency. }\end{array}$ \\
\hline
\end{tabular}




\begin{tabular}{|l|l|}
\hline Tagging & $\begin{array}{l}\text { Tagging is a use visual communication to bring } \\
\text { awareness of important workplace boundaries } \\
\text { Tagging provide information to supplement hazard } \\
\text { or handling labels. Carriers and consignees refer } \\
\text { to markings when accepting hazardous materials to } \\
\text { ensure proper handling of the material as well as } \\
\text { regulatory compliance }\end{array}$ \\
\hline Labeling & $\begin{array}{l}\text { Labels may be used for any combination of } \\
\text { identification, information, warning, and } \\
\text { instructions for use, environmental advice or } \\
\text { advertising. They may be stickers, permanent or } \\
\text { temporary labels or printed packaging. }\end{array}$ \\
\hline Poka yoke & $\begin{array}{l}\text { Japanese term which means mistake proofing. A } \\
\text { poka-yoke device is one that prevents incorrect parts } \\
\text { from being made or assembled, or easily identifies a } \\
\text { flaw or error (Bicheno, 2004).Or "mistake- } \\
\text { proofing," a means of providing a visual or other } \\
\text { signal to indicate a characteristic state. Often } \\
\text { referred to as "error-proofing," poka-yoke is } \\
\text { actually the first step in truly error-proofing a } \\
\text { system. Error-proofing is a manufacturing technique } \\
\text { of preventing errors by designing the manufacturing } \\
\text { process, equipment, and tools so that an operation } \\
\text { literally cannot be performed incorrectly. }\end{array}$ \\
\hline
\end{tabular}

\section{Results and Discussion}

\subsection{Introduction}

All the proposed improvement activities are stated here. The proposed improvements are discussed based on the problems identified from the observation. This is the process flow of the process as shown in Figure 4.1:

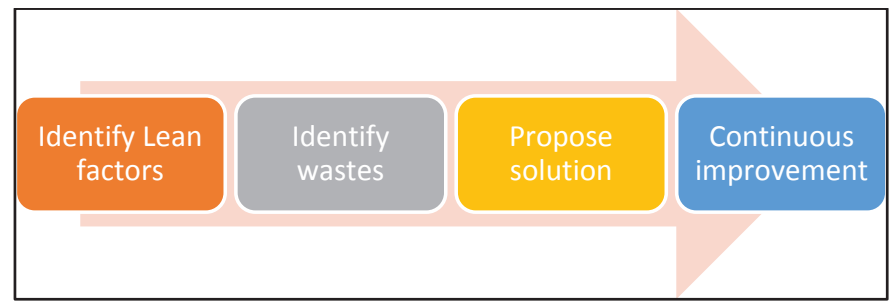

Figure 4.1: Process Flow

The research also covered of a production areas which from peeling, cutting, frying and packaging. Figure 4.2 shows the process flow of production process.

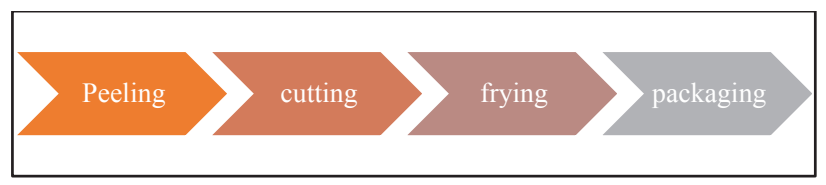


Figure 4.2: production flow of the studied company

\subsection{Lean main factors Practices}

Table 4.1: Lean Factors

\begin{tabular}{|c|c|c|c|c|c|c|c|c|c|c|}
\hline $\begin{array}{l}\text { Author } \\
\text { Factors }\end{array}$ & 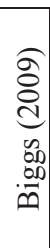 & 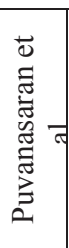 & $\begin{array}{l}\bar{\pi} \\
0 \\
0 \\
: \Xi \\
\overline{0} \\
z \\
z\end{array}$ & 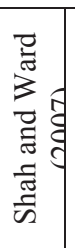 & 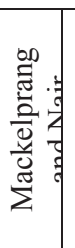 & $\begin{array}{l}\pi \\
\pi \\
0 \\
00 \\
0 \\
3\end{array}$ & 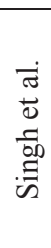 & 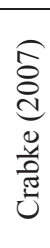 & 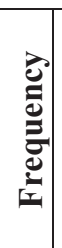 & થ્ \\
\hline $5 \mathrm{~S}$ & $\sqrt{ }$ & $\sqrt{ }$ & $\sqrt{ }$ & & & $\sqrt{ }$ & & $\sqrt{ }$ & 5 & 2 \\
\hline Kanban & $\sqrt{ }$ & $\sqrt{ }$ & $\sqrt{ }$ & $\sqrt{ }$ & $\sqrt{ }$ & $\sqrt{ }$ & & $\sqrt{ }$ & 7 & 1 \\
\hline $\begin{array}{l}\text { Set up } \\
\text { Reducti } \\
\text { on }\end{array}$ & & & $\sqrt{ }$ & $\sqrt{ }$ & $\sqrt{ }$ & & & $\sqrt{ }$ & 4 & 3 \\
\hline $\begin{array}{l}\text { Value } \\
\text { stream } \\
\text { mappin } \\
\mathrm{g}\end{array}$ & $\sqrt{ }$ & $\sqrt{ }$ & & & & $\sqrt{ }$ & $\sqrt{ }$ & $\sqrt{ }$ & 5 & 2 \\
\hline $\begin{array}{l}\text { Just-in- } \\
\text { time }\end{array}$ & $\sqrt{ }$ & $\sqrt{ }$ & $\sqrt{ }$ & $\sqrt{ }$ & $\sqrt{ }$ & $\sqrt{ }$ & & $\sqrt{ }$ & 7 & 1 \\
\hline $\begin{array}{l}\text { Total } \\
\text { Product } \\
\text { ive } \\
\text { Mainte } \\
\text { nance } \\
\text { (TPM) }\end{array}$ & $\sqrt{ }$ & $\sqrt{ }$ & $\sqrt{ }$ & $\sqrt{ }$ & $\sqrt{ }$ & $\sqrt{ }$ & & $\sqrt{ }$ & 7 & 1 \\
\hline
\end{tabular}

Based on the table 4.1, there are five main factors of lean practices based on different authors which are:
a. Just in time (JIT)
b. Kanban
c. Total productive maintenance (TPM)
d. Value stream mapping
e. $5 \mathrm{~S}$ 


\subsection{Benefits of lean tools to the company}

Interview session is done to prove that the objectives of this research are successfully achieved from the respondent's feedback. Table 4.2 shows the results of the respondents.

Table 4.2: interview respondent's opinion about benefits of implement lean tool

\begin{tabular}{|c|l|l|}
\hline Respondent & Opinion 1 & Opinion 2 \\
\hline Respondent & $\begin{array}{l}\text { Implementation of } \\
\text { lean will encourage } \\
\text { operators to produce } \\
\text { only what, amount } \\
\text { and when the } \\
\text { product is needed by } \\
\text { the next operation. }\end{array}$ & $\begin{array}{l}\text { Identifying future } \\
\text { improvement. The } \\
\text { next improvement } \\
\text { to be done is on } \\
\text { plan to make sure } \\
\text { the continuous } \\
\text { improvement is } \\
\text { adopted. }\end{array}$ \\
\hline Respondent & $\begin{array}{l}\text { Less space and } \\
\text { manpower } \\
\text { required to manage } \\
\text { when lean is } \\
\text { implemented. }\end{array}$ & $\begin{array}{l}\text { Ensure all the } \\
\text { operators worked } \\
\text { in proper and } \\
\text { safely environment } \\
\text { to avoid any risk. }\end{array}$ \\
\hline Respondent & $\begin{array}{l}\text { Shorter time is } \\
\text { required in lean } \\
\text { environment system } \\
\text { to make sure less } \\
\text { inventory in a value } \\
\text { stream. }\end{array}$ & $\begin{array}{l}\text { Employees are } \\
\text { encourages to } \\
\text { speak about the } \\
\text { opinions, identify } \\
\text { the problems and } \\
\text { take corrective } \\
\text { action to prevent } \\
\text { problems repeated. }\end{array}$ \\
\hline
\end{tabular}

\subsection{Wastes Identification}

From the process flow, there are 7 waste are identified and occurred which are defects, waiting, inventory, over production, transportation, inappropriate processing, and unnecessary motion by interviewing of three respondents. From interview session found that the biggest problem that the company faced and the appropriate lean tool is suggested to the organization. The table 4.3 below shown how to implement appropriate lean tools based on problems identified. Table 4.3 shows the major wastes occurred in the process flow which are inventory, waiting, defect and overproduction based on the ranking system. Thus, the appropriate lean tools are proposed and suggested based on waste and problems occurred. 
Table 4.3: Identify Wastes

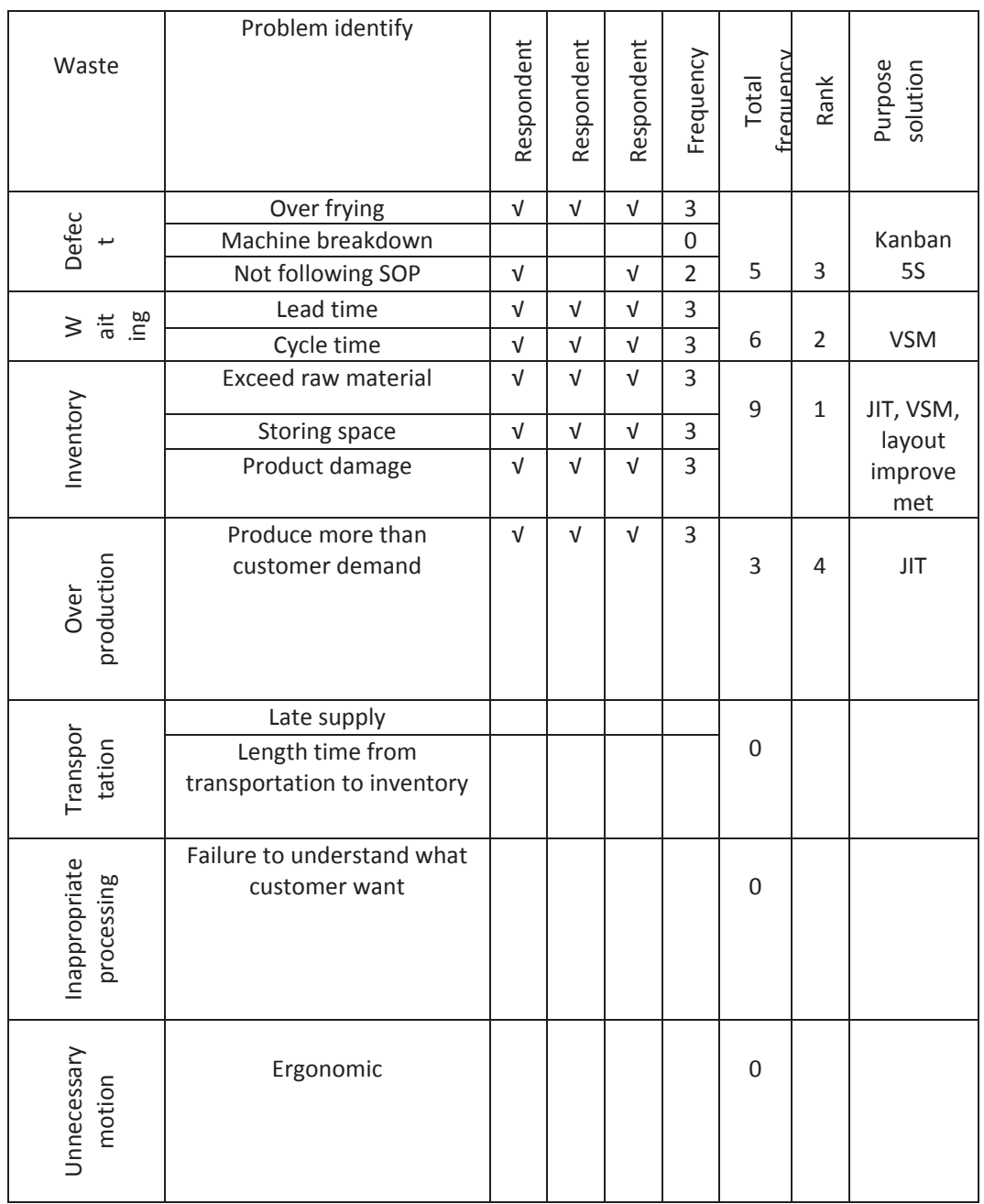

\subsection{Lean Implementation}

The suggested solution for the company to implement lean tools has been identified as shown in the table 4.2 which are:

\subsubsection{S and Tagging System}

The defects occurred because of over frying process. Not all raw materials have same qualities and specific standard. There are all different type of puberty, texture and size. In order to solve the following problem, $5 \mathrm{~S}$ method and tagging is implemented.

\subsubsection{Kanban}

Kanban system is proposed to communicate production requirement between processes. Kanban is card system that contained just few basis information about the batch. The card 
have the information about the process, number of product or parts required and also part numbers of each items. Hence, kanban is also used as signal movement of parts between processes. It is a signaling device that given a permission to withdraw the items in a pull system and gives authorization and instruction for the production to follow the guideline or quantities of items needed. Thus, employees be more alert and have a guideline on doing the process.

\subsubsection{JIT}

Just-in-time or JIT is the system of instantly replace or the production of only what is needed, the amount or quantity needed and when is needed. The wastes that have been found in are overproduction and inventory for JIT elements. This happened due to limitation of raw material, storing space. In this studied company, JIT problems occurred because of the unorganized raw material scheduling. So, employees produced the finish goods more that required or demanded by customer. Because of this JIT problems, there are more problems are occurred such as no space to put the access finished goods and huge bottlenecks created and product delivery aren’t on schedule.

\subsubsection{VSM}

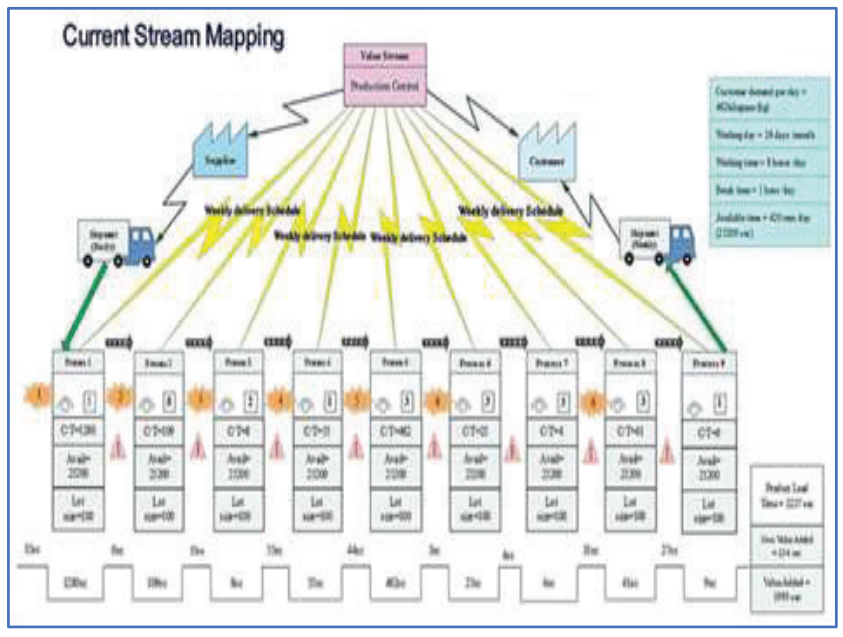

Figure 4.3: Current state stream mapping of studied company

During the interview session with the respective person in the studied company, VSM implementation is suggested. Table 4.3 shows VSM repeated twice as a problem solving for the reduction of lead time and cycle time in the production line. This is because the time taken from one process to the next process are exceed takt time. In one-piece flow production tasks are reduced to their simplest product, errors are reduced and continuous flow of goods enhanced. It is particularly suited for efficient repetitive production process; one-piece flow provides improved quality, bottom-line profits, and continuous output without the need for additional production capacity or staff and also can avoid bottlenecks in a process. Besides, one-piece flow production is able to reduce lead times and to adjust customer demand better than large batch production operations. Figure 4.3 and 4.4 shows the implementation of VSM 
at the studied company. Table 4.4 show the comparison data and time between current state of VSM and future state of VSM at the studied company after VSM have been implemented.

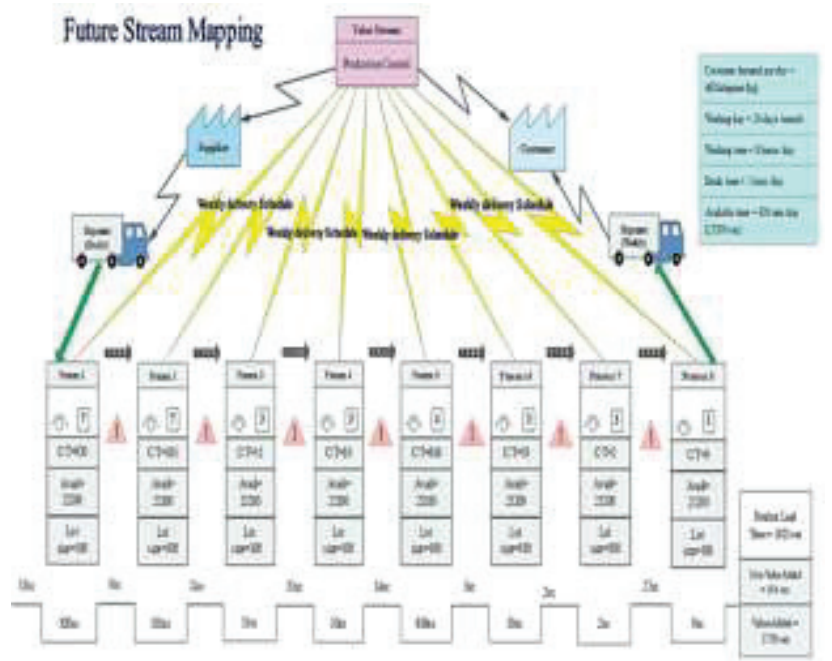

Figure 4.4: Future state value stream mapping of studied company

Table 4.4: Comparison between current and future value stream mapping

\begin{tabular}{|l|l|l|l|l|}
\hline \multirow{2}{*}{ Process } & \multicolumn{4}{|l|}{ Total cycle times } \\
\cline { 2 - 5 } & $\begin{array}{l}\text { Current } \\
\text { State } \\
(\mathrm{sec})\end{array}$ & $\begin{array}{l}\text { Future } \\
\text { State } \\
(\mathrm{sec})\end{array}$ & $\begin{array}{l}\text { Total } \\
\text { reduce }\end{array}$ & $\begin{array}{l}\text { \% reduced } \\
\text { (increased) }\end{array}$ \\
\hline $\begin{array}{l}\text { No. of } \\
\text { Operation }\end{array}$ & $\begin{array}{l}9 \\
\text { process }\end{array}$ & $\begin{array}{l}8 \\
\text { process }\end{array}$ & 1 & 12.5 \\
\hline Process 1 & 1280 & 920 & 360 & 39.13 \\
\hline Process 2 & 109 & 101 & 8 & 7.92 \\
\hline Process 3 & 8 & 11 & -3 & -27.27 \\
\hline Process 4 & 55 & 10 & 45 & 450 \\
\hline Process 5 & 462 & 616 & -154 & -25 \\
\hline Process 6 & 25 & 50 & 16 & 32 \\
\hline Process 8 & 41 & & & \\
\hline Process 7 & 4 & 2 & 2 & 100 \\
\hline Process 9 & 9 & 9 & 0 & 0 \\
\hline Total & 1993 & 1719 & 274 & 13.75 \\
\hline
\end{tabular}

\subsubsection{Layout Improvement}

Layout improvement also been conducted at the studied company. The arrangement of new layout is proposed due to support the lean system by reducing unnecessary movement and to make sure product is delivered at a time through a various operations. Efficient layout is important and needed to make sure all the operation is in the proper arrangement and to eliminate not necessary movement of the items. Figure 4.4 and 4.5 shows the existing of the 
layout and new improvement of layout at studied company. This new layout applied the hybrid lean element such as tagging, lining, kanban and etc.

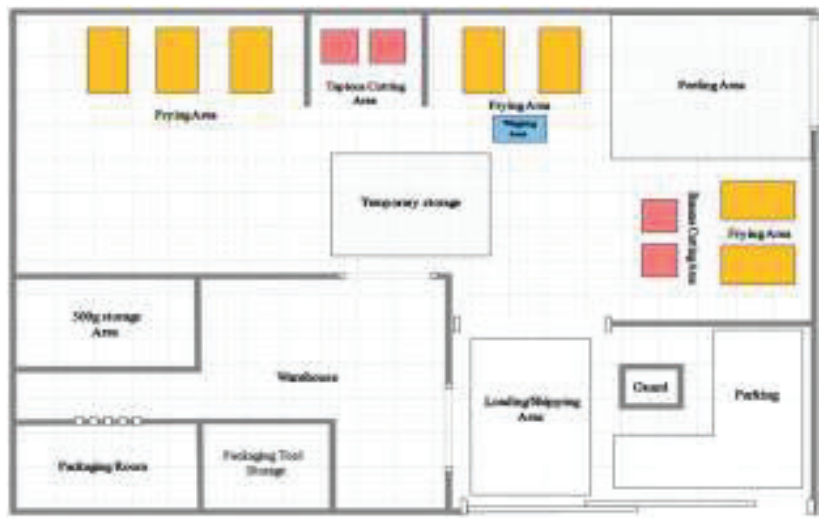

Figure 4.4: Existing Layout

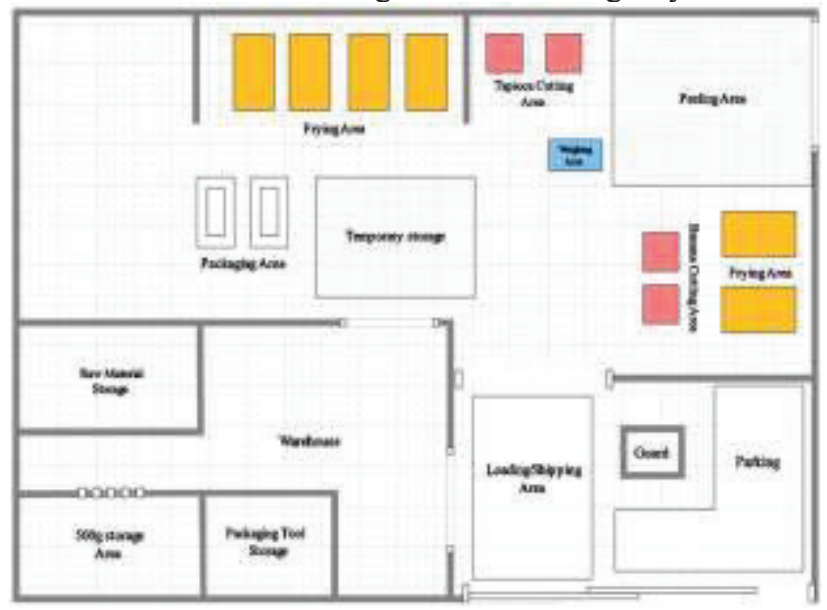

Figure 4.5: New improvement Layout

\subsection{Continuous Improvement}

The implementation to a lean environment cannot be done in a night. A continuous improvement method or procedures is needed to achieve lean environment system. The term of continuous improvement means improvement of service, products, processes, or method with the goal of increasing value and reducing non value added activities to improve product performance, customer service or workplace functionality. Continuous improvement principles, as practiced by the most dedicated manufactures give result and impressive improvement in performance. There is an interesting way to do continuous improvement by implementing lean using hybrid lean tools which is the combination of two or more lean tools into one process. In this research, it combined the element of lean which are 5S, poka yoke, tagging, labeling and visual control for continuous improvement. 
Table 4.5: Pictures analysis of implementation of Hybrid lean tools

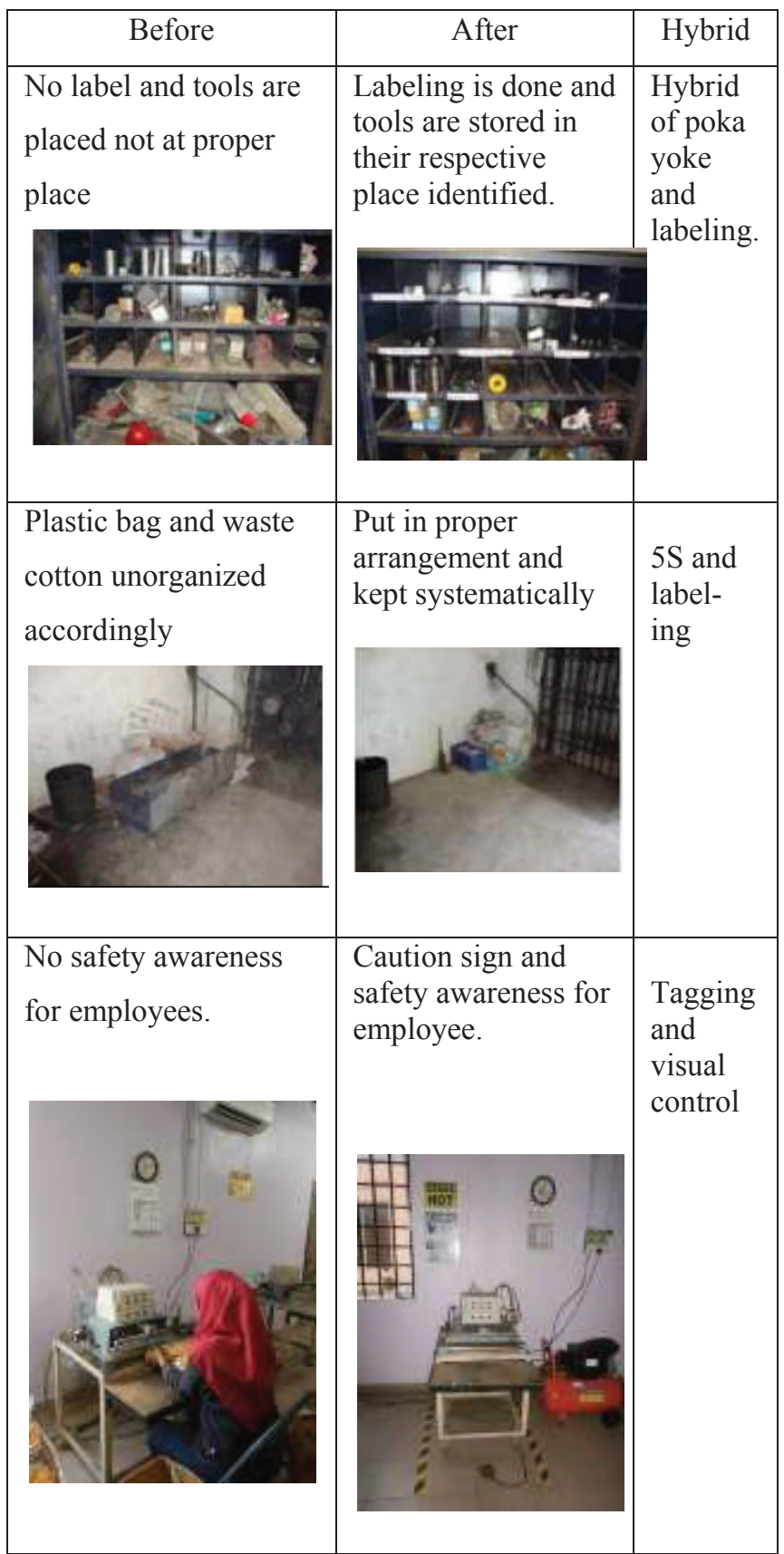




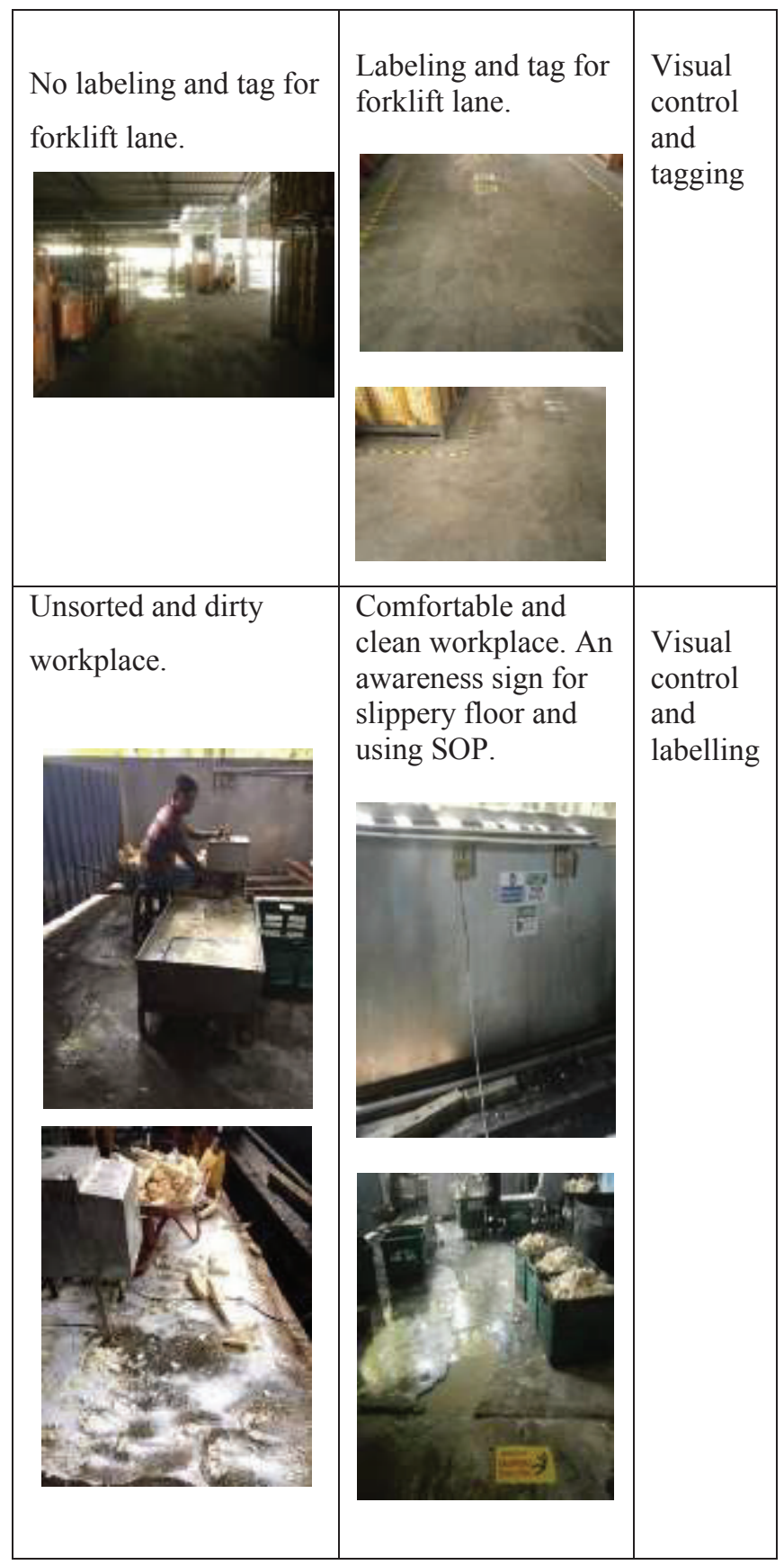

From Table 4.5, the company does not implement the lean tools appropriately. Table 4.4 shows the evident that the company has less awareness of the employee's safety and welfare. The company not provided safety precaution and full SOP for example, gloves during the frying process. Thus, with the hybrid of lean tools such as sign and a visual control, labeling and tagging improved the knowledge on taking a serious action to the safety precaution. 
In addition, things that kept not in proper way affected and waste of the time because need to search for tools in unsorted places. This can delay the activity for the next process. Hence, unsorted things that randomly kept also caused injured to others. Besides, there is no labeling and the tools are place randomly and not in proper arrangement in the rack. The racks become proper arrangement and nice after labeling process is implemented. Employees can easily pick tool without searching and wasting their time. A tagging on the floor also can enhancing of awareness in the workplace. Since the company has no tagging or any visual control for forklift area, employees can easily passing around that area without noticed about the forklift was in a work progress.

\section{Conclusion}

This research is aim to observe whether the organization applied lean management tool in their organization is accomplished. The implementation of hybrid lean tools towards the improvement of the manufacturing company also has been done. Since this is a food company so the hygiene has to be taken care properly. As a result in the analysis, lean tools are not only improved a better workplace but it also reduced a cycle time in a process. In addition, the environment of the company become properly managed and avoided safety precaution. Major of the previous study mentioned that if the organization is providing a better workplace and care on employee's welfare and moral, employees will stay longer and loyal to the company.

Lean manufacturing is proven helps the company to reduce waste and increase the value of the operation. Applying lean philosophy also is needed to maximize the profit and revenue to the company.

\section{References}

1) Ahmad, A.N.A, Hassan S., Husin, N. (2015) Cyber Value Stream System Reduced Waste And Non-Value Added Of Manufacturing Operation, International Journal of Advancement in Mechanical And Aeronautical Engineering, Institute of Research Engineers and Doctors, USA , 4, 205, ISSN:2372-4153

2) Anand, G., and Rambabu Kodali. (2010), "Development of a Framework for Implementation of Lean Manufacturing Systems."International Journal of Management Practice, 4(1). 95-116.

3) Ballé, F., \& Ballé, M. (2005). Lean development. Business Strategy Review.

4) Bicheno, J., \& Bicheno, J. (2004). The new lean toolbox: towards fast flexible flow (3rd ed.). Buckingham: PICSIE Books.

5) Bhuiyan, Nadia, Amit Baghel, and Jim Wilson. 2006. "A Sustainable Continuous Improvement Methodology at an Aerospace Company." International Journal of Productivity and Performance Management, 55(8), 671-87.

6) Browning, T. R., \& Heath, R. D. (2009). Reconceptualizing the effects of lean on production costs with evidence from the F-22 program. Journal of Operations Management, 27(1), 23-44.

7) Gupta, S., \& Jain, S. K. (2013). A literature review of lean manufacturing. International Journal of Management Science and Engineering Management, $8(4), 241-249$.

8) Ho, S. K. M. (2010). Integrated lean TQM model for global sustainability and competitiveness. The TQM Journal, 22(2), 143-158. 
9) Liker, J. K. (2003). The 14 Principles of the Toyota Way: An Executive Summary of the. The 14 Principles of the Toyota Way: An Executive Summary of the Culture Behind TPS, 35-41.

10) Marvel, J. H., \& Standridge, C. R. (2009). A simulation-enhanced lean design process. J.H. Marvel; C.R. Standridge, 2( 1), 90-113.

11) Motwani, J. (2003). A business process change framework for examining lean manufacturing: a case study. Industrial Management \& Data Systems, 103(5), 339346.

12) Rahani, A. R., \& al-Ashraf, M. (2012). Production Flow Analysis through Value Stream Mapping: A Lean Manufacturing Process Case Study. Procedia Engineering, 41.1727-1734.

13) Scherrer-Rathje, M., Boyle, T. A., \& Deflorin, P. (2009). Lean, take two! Reflections from the second attempt at lean implementation. Business Horizons, 52(1), 79-88.

14) Shah, R., \& Ward, P. T. (2003). Lean manufacturing: context, practice bundles, and performance. Journal of Operations Management, 21. 129-149. 